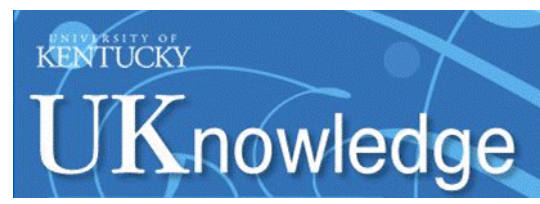

Kentucky Law Journal

Volume 38 | Issue 2

Article 3

1949

\title{
Equitable Relief Against Nuisances
}

William Q. de Funiak

University of San Francisco

Follow this and additional works at: https://uknowledge.uky.edu/klj

Part of the Torts Commons

Right click to open a feedback form in a new tab to let us know how this document benefits you.

\section{Recommended Citation}

de Funiak, William Q. (1949) "Equitable Relief Against Nuisances," Kentucky Law Journal: Vol. 38: Iss. 2, Article 3.

Available at: https://uknowledge.uky.edu/klj/vol38/iss2/3

This Article is brought to you for free and open access by the Law Journals at UKnowledge. It has been accepted for inclusion in Kentucky Law Journal by an authorized editor of UKnowledge. For more information, please contact UKnowledge@lsv.uky.edu. 


\title{
EQUITABLE RELIEF AGAINST NUISANCES
}

\author{
By William Q. DE Funiak
}

The definition of a nusance may be prefaced by the perhaps too obvious remark that it is to be distingushed from a trespass, which is some direct injury to or upon real property committed by one not in any privity of estate or title with the owner or possessor. Such direct injury is usually some actual physical or tangible contact or invasion on or below the surface by the trespasser himself or by some force projected by him. ${ }^{1}$ A nusance has been defined as an unlawful act which causes injury to a person in the enjoyment of his estate, unaccompanied by an actual invasion of the property itself. ${ }^{2}$ The foregoing distmction has been frequently and carefully observed by many courts of equity, although admittedly this is not always the case. Thus, it has been rather common to describe an encroachment, not upon the land itself but upon the space above the land, as a nusance, ${ }^{3}$ although such determination is not uniform. A matter which would not seem to be in accord is the wrong which has developed in recent years, the injury to the plaintiff from continued low level arrplane flights across his land which seems to be described by the courts as a trespass rather than a nuisance. ${ }^{4}$ There are other instances of somewhat longer standing, where the courts have had difficulty in determining whether there is an actual invasion of the property itself, as where damage from allowing imponded waters to escape or percolate to the plantiff's property This is sometimes described as a nulsance, ${ }^{5}$ sometimes as a trespass. ${ }^{6}$

From one standpoint, it might be considered immaterial what the wrong is called, since equity will grant relief in any event where the crrcumstances warrant and where there is no adequate remedy at

* LL.B., Unıv. of Virgınıa, LL.M., Unıv. of San Francisco; Professor of Law, University of San Francisco.

'See de Funak, Equitable Protection against Waste and Trespass, 36 KY. L. J. 255 (1948).

3 . Mfriwin, PrInciples of EQuity 431 (1895).

a "The wrong here complained of was an enroachment, not upon plaintrff's land, but upon the space above the land, and therefore was not a trespass but a nusance." Kafka v. Boz1o, 191 Cal. 746, 218 P 753, 29 A.L.R. 833 (1923), c1ting Wood, Nuisancrs, 33 (3 Ed.) and noted 33 YALE L. J. 557 (1924).

- See Causby v. United States, 60 F. Supp. 751 (1945), noted 58 Harv. L. Rev. 1252 (1945); Burnham v. Beverly Airways, Inc.,-Mass.- 42 N.E. $2 d 575$ (1942); noted 22 B.U.L. RFY. 625 (1942), 28 CORN. L. O. 200 (1943).

"As a nuisance, see Nelson v. Robinson, 47 Cal. App. 2d 520, 118 P 2d 350 (1941).

"As a trespass, see Rueckert v. Sickıng, 20 Ohı App. 162, 153 N.E. 129 (1923). 
law However, the existence of an adequate remedy at law by way of ejectment may exist in the case of a trespass where it would not in case of a nusance, so that what the tort is termed may become of some moment. ${ }^{7}$

Returning, however, to the definition of nusance, further expansion of it is desurable. For, as writers have pointed out, the term nusance is used to designate two distinct groups of wrongs: one, the use of his land by the defendant so as wrongfully to interfere with the plamtiff's reasonable use and enjoyment of his land, as by the creation of unpleasant, unhealthful or dangerous conditions; and two, the interference with some easement or other incorporeal nght of the plaintiff upon or appurtenant to land..$^{8}$

The discussion and definitions so far given are applicable to the so-called private nusance, as distingushed from a public nusance. The former is an injury to one or more particular individuals in distinction from men in general. The latter is an injury to the public generally or to a community or neighborhood or even to some considerable number of persons. ${ }^{9}$ To the extent that the public nursance is especrally injurious to one member of the public or of the community or of the neighborhood, as causing him special damage, it is as to him a private nusance. Just in what way this one member of the public or of the community must suffer injury, so as to constitute a private nusance as to hum, is not always clear. That it should in its nature be special and peculiar to him is a usual view, ${ }^{10}$ but differences in degree have also been recognızed. ${ }^{11}$ The public nuisance encompasses a wide field and involves such matters as the protection of public rights of way and navigation, public welfare, public health, public safety and public morals. Hence, many writers and courts prefer to refer to the subject as the protection of the public or social welfare or the like, rather than by the term public nusance. Whatever designation is applied, it deserves separate consideration. Accordingly the discussion considers first the so-called private nusance.

"Conflict of opinion as to whether act is an adverse user or a dispossession, with reference to availability of legal action of ejectment, see discussion by WAtsit, TREatise on EQuity (1930), Sec. 31.

${ }^{8}$ See, e. g., McClintock; HandBook of Eoutry (1936), 232; WaLsh, op. cil. supra, note 7,170 .

${ }^{2}$ See Merwin, op. cit. supre note 2, pp. 432, 433.

${ }^{10}$ Wesson v. Washburn, 95 Mass. 95 (1866).

${ }^{11}$ Gulf States Steel Co. v. Beverudge, 209 Ala. 473, 96 So. 587 (1923). See also McClintock, op. cit. supra note 8, p. 289: Lawrence, Equity Jurisprudence (1929), p. 954; WaIsH, op. cit. supra note 7 pp. 210, 211. 


\section{When Nuisance Extstent: SpectFic Acts}

What is a use of land so as wrongfully to interfere with a neighbors reasonable use and enjoyment of his property is not subject to precise definition. What is a wrongful interference in one locality may not be $\mathrm{m}$ another. Creation of a condition or manner of using property in a manufacturing or industral district may not there constitute a nuisance but if done in a residential district may be a nu1sance. What is done in a residential district may there constitute a nussance but would not constitute one if done in a rural area. The most that can be sard, perhaps, is that to constitute a nusance, the use must be such as to produce a tangible and appreciable injury to the neighboring property or such as to render its enjoyment especially uncomfortable, inconvenient or dangerous. ${ }^{12}$

Nusances of the type constituting an interference with the plaintiff s reasonable use and enjoyment of his property are of many and varied kinds. ${ }^{13}$ Some illustrations are the generation of noxious, unpleasant or unhealthful odors, ${ }^{14}$ or causing smoke and dust, ${ }^{15}$ or causing noise ${ }^{16}$ or vibrations. ${ }^{17}$ Again, it may be obstructions or encroachments on neighboring property above the surface, ${ }^{18}$ or permitting the escape or percolation or seepage of imponded waters or of sewage or the like onto neighboring property, ${ }^{10}$ or by storage of explosives or mantenance of other dangerous conditions. ${ }^{20}$

Illustrations of the nusance involving interference with an easement or other incorporeal right are such matters as interfering with

12. Sec Hurlburt v. McKone, 55 Conn. 31, 10 Atl. 164 (1886); Campbell v. Seaman, 63 v. Y. 568,20 Am. Rep. 567 (1876).

${ }^{13}$ Besides the illustrations immediately following are others ctted or referred to throughout this article. In addition, numerous annotations will be found in A.L.R. belatung to specific matters or conditions as nusances.

"Pollution of any in residentıal district by gas reservorr. Romano v. Birmingham Ry., L. \& P Co., 182 Ala. 335, 62 So. 677, 46 L.R.A.N.S. 642, ANN. CAS. 1915D 776 (1913).

Sulphuric acid gas from brick kiln mjurious to trees and shrubbery. Campbell ও. Seaman, 63 N.Y. 568, 20 Am. Rep. 567 (1876).

${ }^{35}$ Hulbert v. Califorma Portland Cement Co., I6I Cal. 239, 118 P 928, 38 L.R.A.N.S. 436 (1g11).

in Assembly of God Church v. Bradlev, (Tex. Civ. App.) 196 S.W 2d 696 (1946); Pavne v. Johnson, 20 Wash. 2d 24, I45 P 2d 552 (1944).

"Hennessy v. Carmony, 50 N. J. Eq. 616, 25 Atl. 374 (1892).

" Kafka v. Bozıo, 191 Cal. 746, 218 P 753, 29 A.L.R. 833 (1923), noted 33 YALE L. J. 557 (1924).

"' Percolation from artificial canal, see Nelson v. Robinson, 47 Cal. App. 2d 520, 11 is P 2d 350 (1941).

See Comment, 95 U. of PA. L. Rev. 781 (1947), as to absolute nutsance theory in Pennsylvania.

$\Rightarrow$ People’s Gas Co. v. Tyner, 131 Ind. 277, 31 N.E. 59, 16 L.R.A. 443, 31 Am. St. Rep. 433 (1891), stored explosives. 518.

See annotation, Pesthouse or contagious disease hospital as nuisance, 48 A.L.R. 
a right of way, ${ }^{21}$ interference with ingress or egress, ${ }^{2-2}$ interference with a right of lateral support,,$^{23}$ and interference with riparian easements in streams as by acts of pollution ${ }^{24}$ or diversion of the waters. ${ }^{25}$ The easement interfered with may be an easement of right, or of necessity, or acquired by grant or agreement.

Easements of light and windows, so-called, as of right are not generally recognized in this country, ${ }^{26}$ although they are aquirable by grant or agreement and when so acquired are entitled to equitable protection. $\%$ There 1s, however, some recognition of easements of light as a matter of right in favor of those whose property fronts or abuts on public streets. ${ }^{28}$ It is frequently customary to couple with the term "light" that of "aur", so that statements of the rule read that easements of light and air do not exist as of right. But while technically there may be no protectible easement of air as of right, it is clear that the matter is reached in another way As has been already indicated, pollution of the aur by obnoxious odors, smoke, dust, etc., is enjomable where it interferes with the reasonable use and enjoyment of the plaintiff's property So, though the matter is not reachable as interference with an easement it is reachable under the type of nuisance constituting interference with the reasonable use and enjoyment of property

\section{Anticipated Nuisance}

While generally the nusance is already existent at the time the plamtiff seeks equitable relief, the nuisance need not actually exist $\mathrm{m}$ order to warrant injunction. The reasonable probability of mjury from an anticipated nuisance will warrant injunction in a proper case.": Anticipation of a nusance may be more easily determmed where there

${ }^{21}$ Stallard v. Cushing, 76 Cal. 472, 18 P 427 (1888); Tucker v. Howard, 12) Mass. 361 (1880).

—Shamhart v. Morrison Cafeteriea Co.,-Fla.-- 32 So. $2 d 727$ (1918).

$\approx$ Trowbridge v. True, 52 Conn. 190, 52 Am. Rep. 579 (1884).

There is very little equitable authority on this question, according to Warsit, Treatisf on Equity (1930), p. 183. But see Merwin, Principles of Equity (I895), pp. 434, 435. And see Unversal Realty Co. v. Fesler, 179 MId. 635, 22 A. 2 (l 418 (1911). as to right of support from party wall.

: Lockwood Co. v. Lawrence, 77 Me. 297, 52 Am. Rep. 763 (1885); Farley v. Crystal Coal \& Coke Co., 85 W Va. 595, 102 S.E. 265, 9 A.L.R. 933 (1920). Sce an. notation, Injunction Agaunst Pollution, 46 A.L.R. 8.

$\approx$ Harding v. Stamford Water Co., 4 I Conn. 87 (1874); Amsterdam Knttung Co. v. Dean, 162 N.Y. 278,56 N.E. 757 (1900).

" This was remarked upon over 50 years ago by Mrerwis, Principles of Enum? (1895), p. 435, pointing out that the rule is otherwse in England and formerly in Massachusetts.

$\approx$ Hennen v. Deveny, 71 W Va. 629, 77 S.E. I42. L.R.A. 1917A 524 (1913).

$\approx$ See. e.g., Lahr v. Metropolitan Ry., 104 N. Y. 265,10 N.E. 528 (1887).

${ }^{2}$ McPherson v. Frrst Presbyterian Church, 120 Okla. 40, 248 P 561, 51 A.L.R. 1251 (1926). 
has been past conduct to judge by For example, the construction of a church has been enjomed on the ground that its manner of use would constitute a nusance, where past conduct of the congregation in holding revival meetings at night on the premises in a tent had consisted of singing and shouting in loud voices heard as far as half a mile away ${ }^{30}$

But relief is not warranted if it does not appear that the danger to the plantiff is real and immediate and that the mjury will be material. ${ }^{31}$ Where a thing or condition is not in itself a nusance, that is, is not describable as a nusance per se, but will result in a nusance only from its manner of mantenance or operation, its establishment or construction should not be enjomed merely upon the possibility that its management or operation could be such as to make it a nuisance. ${ }^{32}$ In the case of the church previously referred to, the church in itself was not a nusance per se but its manner of use, reasonably to be foretold in advance, would constitute a nuisance.

\section{Prescription-Coning to a Nuisance}

Whether a right may be acquired by prescription to mantan a nusance is a question upon which the authorities are confused. Upon analysis, the logical view develops that no such right is acquirable. ${ }^{33}$ Where one maintains a certain condition upon his land, such condition cannot constitute a nusance to someone else until someone is affected by the condition. Suppose that the defendant mantams a certam condition upon his land and has done so for many years. The plamtiff now acquires land in the vicinity and moves upon it. He then discovers that his reasonable use and full enjoyment of his property is serıously affected by the condition mantamed by the defendant and will continue to be so affected. The condition may not previously have been mjurious to anyone, but as to the plantiff it constitutes a freshly instituted mjurv As to hum, it has not been maintanned long enough to give any so-called prescriptive right to the defendant. ${ }^{34}$ If

$\therefore$ A sisembly of God Church v. Bradley, (Tex. Civ. App.) 196 S.W 2d 696 (1946).

:I Vaszil $\because$ Molnar, 133 N. J. Eo. 577, 33 A. 2d 743 (1943), where the apparent intention of the defendant to keep chickens in his back yard, adjoining the planntiff.. premises, was held not to create an apprehension of a nusance.

3: Collins v. Lanıer, - - Ga. - 40 S.E. 2d 424 (1946), noted 9 GA. BAR Jour. 325 (1947); Esstck v. Shillam, 347 Pa. 373, 32 A. 2d 416, 146 A.L.R. 1399 (1943).

Construction of airport not enjoined since arrport was not a nuisance per se and would become one only if improperly managed. Warren $T p$. v. City of Detroit, -Mich.-14 N.W 2d I34 (1944), noted 29 MINN. L. REv. 38 (1944).

${ }_{30}$ See Hall v. Budde, $293 \mathrm{Ky} .436,169$ S.W 2d 33, 167 A.L.R. 1361 (1943).

"Hall v. Budde, supra note 33. See annotation, "Coming to a nuisance" as a defense or operating as an estoppel, 167 A.L.R. 164; Comment, Defense of unoc cupled property against nuisance, 21 Notre Daire Law 358 (1946). 
it be maintaned that the prescriptive right of the defendant has been acquired against the land of the plantiff before he obtaned or entered upon it, this would permit the defendant vurtually to condemn to his own private purposes and uses all the property surrounding hum and allow the defendant to limit the uses to which the surrounding property could be put. ${ }^{35}$ Even in the case of vacant land already owned but not yet occupied by the plaintiff, injunctive relief has been allowed the plaintiff on the ground that future enjoyment and benefit of his land would be interferred with when it came to be occupied. ${ }^{36}$

If the plaintiff at the time of acquuring his property is aware of the condition maintamed by the defendant, is he estopped or in any way equitably barred from seeking relief? The mere fact that he knew of the condition is in itself no indication that he knew or realized the effect it would have upon him in the ownership or occupancy of his property Even if the plaintiff knew of the effect it would have upon his use and enjoyment of his property, he is not thereby estopped from seekmg equitable relief, if his use of $h: s$ property rather than the defendant's use of the defendant's property is in conformity with the general use of property in the locality It must always be borne in mind that the general nature or use of the neighborhood may affect right to relief. One could not move into what is a manufacturing neighborhood for a residential purpose only and insist on the prevalence of the same conditions obtaining in a resıdential neighborhood. ${ }^{37}$

But has a defendant acquired a prescriptive right against a plamtiff who has actually occupied nearby property for, say, twenty years and not within that time objected to the condition maintaned by the defendant? No, for what actually is the case is that the plaintiff is estopped or barred by laches from obtanning equitable relief. If the defendant is described as having acquired a prescriptsre right, it is against the plaintiff only and personally If the latter now sold to a third person, the third person would be faced with a condition that was a nursance as to him as being freshly instituted, which is the situation just previously discussed. In regard to the foregoing, it is to be noticed that even though the plaintiff has occupied his property for years in the vicinity of the defendant, durng which period the defendant has maintaned a certain condition, the condition so mamtamed may not during that period have constituted any nussance to

${ }^{35}$ See, espectally, Hulbert v, Californıa Portland Cement Co., 161 Cal. 239, 118 P 928, 38 L.R.A.N.S. 436 (1911); Campbell v. Seaman, 63 N. Y. 568,20 Am. Rep. 567 (1876).

${ }^{38}$ Romano v. Birmingham Ry., L. \& P Co, 182 Ala. 335, 62 So. 677, 46 L.R.A.N.S. 642, Ann. Cas. 19150776 (1913).

${ }^{3 *}$ Effect of location of property, see annotation, 167 A.L.R. 1364, at p. $137 \%$ et seq. 
the plantiff. But upon the plantiff making another but reasonable use of his property, the condition now interferes with him. If such is the case, it may then for the first time become a nusance as to him and be enjomable and no so-called prescriptive right exısts in favor of the defendant. ${ }^{38}$

So far the discussion has concerned the type of nusance that is an interference with the reasonable use and enjoyment of property Where the nusance results from interference with an easement, it appears common to declare that a prescriptive right to interfere may be acquired, or that the easement may be lost by prescription. In a situation, for instance, where riparian owners are entitled to use a certam amount of water from a stream and the upper owner takes more than he is entitled to, to the detriment of the lower owner, who does not object for many years, it might well be argued that the upper owner has acqured a prescriptive right to take the additional water and that the lower owner has, correspondingly, lost his right to the former amount of water by reason of prescription. But, on the other hand, is this any more than a matter of estoppel or laches so far as concerns this particular lower riparian owner? If he now sells his ruparan property to a thrrd person, is this "prescription" effective agamst the thrrd person? He has no notice from anything of record and may have no actual notice otherwise. There is no reason why the rule should be any different here from that in the case of mterference with use and enjoyment of property ${ }^{3 s a}$

\section{Relief Avallable}

If the circumstances justify it, the injured party may abate the nuisance himself, that is, resort to self help. This may be feasible in some instances and warranted by immediate necessity, as where egress to a highway is a matter of right, is necessary and has been wrongfully interferred with by the padlocking of a gate. ${ }^{39}$ This right to resort to self help is sometimes recognized and provided for by statute." Whether or not it has been recognized by statute, it has been

$\therefore$ For example, the defendant for years maintained two mortars against a paris wall for the purposes of pounding loaf sugar, etc. Upon the plantiff thereafter crecting his consulting room next to the party wall, the condition then became an enjounable nusance. Sturges v. Bridges, Il Ch. Div. 852 (I879).

is Cases on prescriptive right to pollute stream, see annotation 46 A.L.R. 68.

"I can recall smashing a padlock myself, upon an occasion when my familys only access to the highway was so blocked. No further attempt was ever made by the offender to repeat the nusance.

"As an illustration of statutory authorization of self help, see Cat. Civ. Code, sec. 3501-5.503. It is specified that the abatement mas be accomplished without ubjecting the mjurcd party to liability for breach of the peace. Where the numance results from mere onission by the wrongdoer, notice to hm of the minten. thon to abate it is required. 
uniformity recognized by courts of equity as a proper method of abatung a nuisance where the curcumstances warrant.:11 We sometmes find courts of equity denying the ard of equity on the ground that the remedy by way of self help is entirely adequate as a means of relief. Denial on such ground may well be confined to situations not productive of substantial mjury ${ }^{22}$ There is no doubt, however, that any right of self help should be exercised with caution for it may well lead to actual hostilities of some sort, with the resultant calling of a policeman, where one is available, who will probably be totally Ignorant of the injured party's right to use self help. Resort to the equity powers of a court, if permissible, may provide a more dignified method of procedure.

But as in the case of trespass, the jurisdiction of equity depends upon whether the nusance is continuous or repeated or merely casual and temporary In the former case, continued or recurring nature of the nusance, threatening permanent or irreparable injury, renders the remedy at law madequate and warrants equitable relief. In the latter case, the injured party is left to his remedy at law In addition to the award of equitable relief, the plantiff may also recover damages. The amount of damages may be fixed by the court where the exact extent of detriment is not susceptible of exact pecuniary compensation..$^{43}$

So far as concerns the requisite of property or a property right to warrant equitable jurisdiction, it will be seen that this requisite is definitely present in the case of a private nussance.

Acts constituting nusances are frequently described by statute as crimes but this does not prevent resort to the and of equity where the remedy obtamable through crimmal proceedings is not so speedy, efficient and adequate as that obtamable in equity to prevent ureparable or permanent injury ${ }^{44}$

Where the question is rased as to whether the act or condition constitutes a nussance or as to the right, title or interest of the plamtiff as a warrant or basis for obtainmg equitable relief, must this question be settled at law before he may proceed for equitable relief?t5

11 Where the injured party has not encouraged the maintenance of the nuisance he may act to remove it without giving notice of his intention. Otherwise, he should give notice of, his intention to resort to self help, according to the view followed in many jurisdictions.

${ }^{42}$ See Smith v. Holt, 174 Va. 213. 5 S.E. 2d 492, 128 A.L.R. 1217 (1939). Availability of self help not preventing obtaining of equitable ald, see Gostma v. Ryland, 116 Wash. 228, $199 \mathrm{P}$ 298, 18 A.L.R. 650 (1921).

sadson v. Los Angeles Suburban Gas Co., 157 Cal. 168, 106 P 581, 26 L.R.A.N.S. 183, 21 Ann. Cas. 1247 (1910).

"See Ingersoll v. Rousseau, 35 Wash. 92, 76 P 513, I Anp. Cas. 35 (1904).

${ }^{45}$ See Lewis, Injunctions agamst N'utsances and Rule Requiring Plamtiff to Establish his Right at Law, 47 U. of PA. L. REv. 289 (1908). See also McRae, Dcvelopment of Nutsance in Early' Common Law, I FLA. L. REv. 27 (1948). 
Where law and equity are admmistered m separate courts, it would seem that the plaintiff would first have to have the question of his right, title or interest or the existence of a nusance decided in his favor in a court of law, as in the case of trespass. But while this requirement may be found in some of those jurnsdictions, ${ }^{46}$ it appears to have been abandoned or ignored in others. ${ }^{47}$ In code states, of course, merger of law and equity has done away with any difficulty by permitting disposition of all questions arising, both legal and equitable, $m$ the same proceeding. But even so, $m$ the code states, the matter of having a jury determme the legal question rased seems generally to be ignored and the court, in the exercise of its equitable powers, determines all questions. ${ }^{48}$

Where mamtenance of the particular condition alleged to be a nusance has been authorized by law, as by legislative or other official license, is it nevertheless enjoinable? Where the authorization permits construction or maintenance or operation of something which does not necessarily produce an injurious result, but such result flows from a particular construction or mantenance or operation, the authorization is no defense to the application for equitable relief. ${ }^{ \pm 9}$ But where an act has been expressly authorized which must mevitably result in injury, what would otherwise be a nusance is said to be legalized."0

The defenses customarily available in suits for equitable relief agamst torts, such as laches, unclean hands, and balancing of equities or conveniences, are available in suits to enjoin acts alleged to constrtute nusances. Since I have discussed these generally at another place, I do not include a repetition here. ${ }^{51}$

\section{Public Nंuisances}

$\Lambda$ public nussance is defined as such an inconvenience or troublesome offense as annoys, or infrunges on the rights of, the whole community or some appreciable portion of it and not merely of some par-

\footnotetext{
"Sce Parks v. Parks, 121 Me. 580, 119 A. 533 (1922).

${ }^{17}$ Sec Phelps v. Winch, 309 Ill. 158, 140 N.E. 847 (1923); Sullivan v. Jones $\$$ Laughlin, 208 Pa. 540, 57 A. 1065 (1904).

Waver b not rasing question in equity court, see Coast Co. v. Sprng Lake, 56 У. J. E. 615.36 A. 21 (1898).

is Sec discussion by Professor Durkee, Cases on Equiry (1928), pp. 453, 454, notes.

:"Sce Katencamp v. Union Realty Co., 6 Cal. 2d 765, 59 P 2d 473 (1936).

so See Sayre v. Newark, 60 N. J. Eq. 361, 45 A. 985, 48 L.R.A. 722, 83 Am. St. Rep. 629 (1899): Dudding v. Automatic Gas Co., - Tex. - 193 S.W 2d 517 (1946), noted 25 TrX. L. REv. 96 (1946).

"See de Funiak, Requsites for Equitable Protection Against Torts, $37 \mathrm{KY}$. L. J. 29 (Nov., 1948).
} 
ticular person. ${ }^{52}$ The effectiveness of the interposition of equity and of its injunctive relief to prevent or to put a stop to such a situation is readily apparent..$^{53}$

Somewhat briefly, it may be sard that the first instances of protection of the public in early English equity jurisprudence involved the public health and purprestures. ${ }^{54}$ That equitable interposition is to be restricted to these matters has been indicated in some of the older American cases. ${ }^{\breve{a}}$ However, in most jurisdictions today the extent to which the jurisdiction and and of equity may be invoked encompasses a wide range involving the public welfare generally As well as protection of the public health, ${ }^{\mathbf{5} 6}$ equity protects such matters as the public safety, ${ }^{57}$, property generally of the public, ${ }^{58}$ public morals ${ }^{59}$, and the like. ${ }^{60}$

Because of the protection of the rights of the public or a large part thereof is involved, it has seemed preferable to many courts and legal writers to term the matter the equitable protection of the public or social welfare rather than equitable protection agamst public nusances. Since the extent of equitable protection of the public has, in most jurisdictions, gone far beyond the original consideration of what constituted a public nusance, there may well be justification for the preferred termmology referred to.

Since the jurisdiction of equity has been so dependent upon the protection of property right, ${ }^{\prime 1}$ it is common to find the older cases expressing an unwillingness to enjom as a public nusance a situation which contravened public policy or threatened the general or social

\footnotetext{
\#̈ See Moore. CYc. LAW Dicr., 3d Ed.

${ }^{3}$ Discussion, see Leflar, Equilable Protection of Public IIrongs, 14 TEx. L. REv. 427 (1936).

it Walsh, Treatise on Equitr (1930), Sec. 37, Charee, Cises on Equitable Rr Liff Against TORTs (1924), pp. 438-140. Purprestures, see post.

$\approx$ See, e.g., State v. Uhrig, 14 Mo. App. 413 (1883).

50 Village of Pine City v. Munch, 42 Alinn. 342,44 N W 197 (1890)

${ }^{5}$ See State ex rel. Hopkins v. Howat, 109 Kan. 376, 198 P 686, 25 A.L.R. 1212 (1921), error dismuss?d 258 U.S. 181, 42 S. Ct. 277 65 L. Ed. 550 (1921).

os Georgia v. Tennessee Copper Co., 206 U.S. 230, 27 S. Ct. 618, 51 L. Ed. 103s (1906).

Injunction to protect property interests of state in food fish in coastal waters on ground remedy at law madequate, see People v. Monterey, etc., Co., 195 Cal. 51 s, $234 \mathrm{P}$ 598. 38 A.L.R. 1186 (1925).

sa See discussion, post.

wo Enjounmg u urous practices considered mumous to public welfare, see State ex rel. Smith v. McMahon, 128 Kan. 772, 280 P 996, 66 A.L.R. 1072 (1929), noted 30 Col. L. REv. 125, 15 CoRN. L. Q. 472, 43 HARv. L. REv. 499, It MINN. L. RIN. 690. 39 YaLE L. J. 590: Commonwealth v. Continental Co., 275 Ky. 238, 121 S.W 2d 19 (1938), noted 1 LA. L. REv. 619; State ex rel. Goff v. O'Neil, 205 Minn. 366, 286 N.W 316 (1939), noted 34 ILL. L. Rev. 397. Contra, see people ex rel. Stephens v. Sec combe. 103 Cal. App. 306, 284 P 725 (1930), noted 18 Cillif. L. Rex. 328.

ol Aspects of this have been discussed by me in previous articles, $36 \mathrm{Kr}$. L. J. 7 (1947), $37 \mathrm{Kr}$. L. J. 29 (1948).
} 
welfare rather than threatening property rights. ${ }^{62}$ Even where the courts have inclined to protect the public welfare or morals or the like, it has frequently been pitched upon the property element by statıng that the court is enjoining the use of his property by the defendant in a manner that would threaten the public welfare, morals or the like.:3 Although this reasoning has frequently seemed to soothe the court and make it feel that it has not been forgetting the property element as a basis of equity jurisdiction, it will be noticed that the reasoning is somewhat twisted. If property is a necessary element of equity jurisdiction, it has been the fact that property or rights therem are being protected from irreparable injury However, what may be termed the development of social consciousness in many courts has brought about their exercse of equity jurisdiction to protect the public or social welfare, without regard to the question of property, ${ }^{64}$ and we thus find a situation in which definitely equity acts as a source of the only adequate relief without regard to the historic but sometimes crippling limitation upon its exercise of jurisdiction.

But leaving aside the property element, many courts display a great deal of caution about determining that acts or conduct constitute a public nusance, especially as being injurious to public morals. Since standards of morality may change from one period to another or differ between one state and another, this cautrous attitude is understandable.": Changing standards certanly tend to make decissons of another period or of another jurisdiction doubtful authority

\section{PuRprestures}

Reference has already been made to purprestures and, somewhat belatedly, we turn to a brief consideration of them. A purpresture is defined as an enclosure or appropration to his own use by an individual of a part of a common or public doman. Usually, it involves enclosure or appropriation of a public right of way or public right of mavigation."1i Strictly, unless such enclosure or appropriation inter-

"s See e.g..Attorney General v. Utuca Ins. Co., 2 Johus. Ch. (N. Y.) 371 (1817).

" Repars v. Commonwealth $131 \mathrm{Kv}$. 807 115 S.W 1101 (1909).

"State eq rel. Smith v. McMahon, stipra note 60.

"No mvasion of a property right need be shown in order to justify the use if an injunction to abate a public nuisance at the instance of the state. The rule as to property rights applies only when the complainant is a private individual attempting to abate a public nusance." State v. Phoenx Sav. Bank \& Trust Co., 198 P 2d 1018 (Arta., 1948).

is Responsibility declared to rest upon the legislature to determme standards of public morality, violations of which shall constitute public nussances, see People $v$. L.1m. 18 Cal. 2d 872, 118 P 2d 472 (1941), where operation of gambling house was sought to be enjomed.

"See MOORE Cyc. Law Diet, 3d Fd. 
feres with the public's use of the right of way or navigation, it is not a public nusance.

Some American cases, partıcularly the earlier ones, influenced by English decisions, have taken the view that if the purpresture does not constitute a public nusance or does not cause irreparable injury or does not interfere with legislative control, equitable relief is not available to the state and the legal remedy of ejectment must be pursued. ${ }^{67}$ The better view is that a purpresture need not also be a public nusance to warrant equitable relief where that is the most adequate means of relief to the state or to the people of the state. ${ }^{18}$ Where it is a public nusance in that it interferes with the public in its use of public rights of way or navigation, injunctive relief undoubtedly is proper to prevent this interference. ${ }^{69}$

\section{Act or Conduct As a Crane}

The mere fact that an act or conduct is in violation of a penal statute does not render such act or conduct a public nussance. Equity does not enjoin an act merely because its commission will constitute a crime. ${ }^{70}$ The act or conduct must be such as would constitute a public nusance even in the absence of statute, to warrant enjoining the act or conduct. ${ }^{71}$ If to allow the commission or continued commission of certam acts or conduct will result in urreparable injury to the public, equity will enjoin such commission even though the commission thereof is described by statute as a crime. ${ }^{72}$ However, it is not unusual for statutes to provide that an act is a crime and, as well, a public nusance and enjomable as such. Indeed, by statute an act may be declared to constitute a public nusance although previously, in the absence of statute, it had not been considered to constitute a public nuisance.

\footnotetext{
${ }^{\circ}$ People v. Davidson, 30 Cal. 379 (1866).

see Story, Equity JurIsprudence (14th Ed., 1918), Sec. 1248 et seq.

Injunction denied where purpresture did not constitute public nusance and defendant had easement as riparian owner to reach navigable portion of stream, sec People v. Mould, 37 App. Div. 35.55 N.Y.S. 453 (1899).

${ }^{\infty}$ Hibbard \&. Co. v. Chicago, 173 Ill. 91, 50 N.E. 256 (1898).

Unusual illustration of purpresture, see Attorney General v. Williams, 174 Mass. 426, 55 N.E. $77,+7$ L.R.A. 314 (1899).

${ }_{70}$ People v. Steele, 4 Cal. App. 2d 206, 40 P 2d 959, 41 P 2d 946 (1935); Commonwealth v. Smith, 266 Pa. 511, 109 A. 789, 9 A.L.R. 922 (1920).

"It is apparent that it is often sought to prevent certan conduct by means of equitable remedies where resort to crummal prosecutions have proved unavailing because of unwillingness of juries to convict. Whether this resort to equity will proce successful will usually depend upon the attitude and belief and prejudices of the judges. Compare People v. Steele, supra note 70, with People v. Laman, 277 N. Y. 368, 14 N.E. 2d 439 (1938), noted 24 CoRN. L. Q. 118, 25 VA. L. Rev. 99.

In re Debs, 158 U.S. 564, I5 S. Ct. 900, 39 L. Ed. 1092 (1895); People v. Laman, supra note 71 ,
} 


\section{Procedure}

Suits to enjoin public nussances ordinarily are provided by statute to be brought by the state attorney general or other designated public officer, in the name of the state or of the people of the state. Usually the suit may not be brought by and in the name of individuals, although the suit is frequently brought in the name of the state on the information of (ex relatione) the party or parties immediately interested in or affected by the nusance. ${ }^{73}$ On occasion, by statute, the suit may be brought by and in the name of members of the public interested or affected by the nusance. ${ }^{74}$ 
